\title{
WEBSITE-BASED TECHNOLOGICAL PEDAGOGICAL AND CONTENT KNOWLEDGE FOR LEARNING PREPARATION OF SCIENCE TEACHERS
}

\author{
Insih Wilujeng ${ }^{1 *}$, Nurgan Tadeko ${ }^{2}$, Wipsar Sunu Brams Dwandaru ${ }^{1}$ \\ ${ }^{1}$ Universitas Negeri Yogyakarta, Indonesia \\ ${ }^{2}$ Universitas Tadolako, Indonesia \\ *e-mail: insih@uny.ac.id
}

\begin{abstract}
This study produces technological pedagogical and content knowledge (TPACK) instruments, which conventionally use print modules. The aims of this study were 1) to develop appropriate website-based TPACK instruments, and 2) to determine the effect of the produced website-based TPACK instruments toward the pedagogy competence of Science teachers in their learning preparation in the classroom. The methodology used was based on the ADDIE stages which stand for analyze, design, develop, implement, and evaluate. The results of this study include 1) instructions for producing TPACK instruments based on the results of synthesis; 2) instructions for making a website format based on the synthesis results; 3) TPACK framework design in website content; 4) TPACK instruments validation results; and 5) website validation results. Moreover, limited and field tests were conducted upon the website-based TPACK instruments to determine their effect toward the pedagogy competence of Science teachers. Quantitatively, the TPACK instruments scored 70 out of 76, while the website scored 60 out of 90 . Finally, the limited and field tests results showed that website-based TPACK instruments positively affect the pedagogy competence of Science teachers in their learning preparation in the classroom with an overall Good category and a Very Good category for the usage evaluation from the users.
\end{abstract}

Keywords: website based-TPACK, science teacher, learning preparation

\section{PENGETAHUAN KONTEN PEDAGOGIS DAN TEKNOLOGI BERBASIS WEBSITE UNTUK PERSIAPAN PEMBELAJARAN GURU-GURU SAINS}

\begin{abstract}
Abstrak: Kajian ini menghasilkan perangkat pengetahuan konten pedagogis dan teknologi (Technological Pedagogical and Content Knowledge-TPACK) yang saat ini secara konvensional masih menggunakan modul cetak. Tujuan dari penelitian ini adalah 1) mengembangkan perangkat TPACK berbasis website yang layak, dan 2) mengetahui pengaruh penggunaan perangkat TPACK berbasis website terhadap kompetensi pedagogi guru IPA dalam mempersiapkan pembelajan di kelas. Metodologi yang digunakan berdasarkan tahapan ADDIE, yaitu: analisis, perancangan, pengembangan, implementasi, dan evaluasi. Penelitian ini menghasilkan: 1) format petunjuk untuk menghasilkan perangkat TPACK berdasarkan hasil sintesis; 2) petunjuk format pembuatan website berdasarkan hasil sintesa; 3) desain kerangka TPACK dalam konten website; 4) hasil validasi perangkat TPACK; dan 5) hasil validasi website. Selanjutnya, ujicoba terbatas dan lapangan dilakukan terhadap perangkat TPACK berbasis website untuk menentukan efeknya terhadap kompetensi pedagogi guru IPA dalam mempersiapkan pembelajaran di kelas. Secara kuantitatif, nilai perangkat TPACK yang didapatkan, yaitu 70 dari nilai maksimal 76, sedangkan nilai website yang didapatkan, yaitu 60 dari 90 nilai maksimal. Hasil penelitian juga menunjukkan bahwa perangkat TPACK berbasis website layak untuk digunakan sebagai persiapan guru sebelum melakukan pembelajaran. Lebih jauh, hasil ujicoba terbatas dan lapangan menunjukkan bahwa perangkat TPACK berbasis website ini mempengaruhi secara positif kompetensi pedagogi guru IPA dalam mempersiapkan pembelajaran dalam kelas dengan kriteria Baik.
\end{abstract}

Kata Kunci: TPACK berbasis website, guru sains, persiapan pembelajaran 


\section{INTRODUCTION}

Teachers today are not only expected to help students in learning, but also to strengthen students' technological literacy and encourage more advanced technology. Facing students in the digital era, teachers must be smart about what and how to use technology-based instructional approaches (Widyastono, 2016; Indonesian Science Educators Association, 2015; National Science Teachers Association, 2012). In 2002 a survey in American universities showed that 1.6 million students took at least one online-based subject (Allen \& Seaman, 2003).

However, technology as a partner in learning has its own problems. Some teachers have mastered technology and some are only limited to projector devices (Purwaningsih, 2016). In the United States, the use of projectors, interactive boards, and digital cameras by teachers are $72 \%, 57 \%$, and $49 \%$, respectively (Gray, Thomas, \& Lewis, 2010). On the other hand, Novkovic-Cvetkovic \& Stanojevic (2017) found the need for innovative interventions in education because of big gaps between scientific achievement, technical of the workforce, and the quality of the education process. It is qualitatively showed that $53.06 \%$ of teachers prefer individual learning and $38.77 \%$ use media. Regarding teachers, the study of prospective teachers in the use of material for teaching science has found that the level of association of materials with technology is very low even though teachers can improve pedagogical skills through training in technology (Balçın \& Ergün, 2017).

Hence, a solution is needed in integrating technology with learning in the classroom. One such effort is by using Technological Pedagogical and Content Knowledge (TPACK) framework (Sheffield, Dobozy, Gibson, Mullaney, \& Campbell, 2015). TPACK has three main components namely Technological Knowledge (TK), Pedagogical Knowledge (PK), and Content Knowledge (CK). TK is the accuracy of teachers using technology according to standards and prevalent to improve students' understanding of the concepts being taught (Hunter, 2015; Koehler, Mishra, \& Cain, 2013; Gray, Thomas, \& Lewis, 2010). PK is the ability of teachers to plan learning according to school, students, curriculum, and teachers' experience conditions (Doering, Veletsianos, Scharber, \& Miller, 2009; Undang-Undang RI 2005 No.
14). CK is the ability of teachers to comprehend and comprehensively master subject matter in accordance with the applicable curriculum designs (Hunter, 2015; Niess, 2005; Van Driel, de Jong, \& Verloop, 2002).

TPACK is an ability that should be practiced by science teachers. This ability may also improve the quality of science teachers and the ability of students (Maryati, Prasetyo, Wilujeng, \& Sumintono, 2019). Studies conducted in Hong Kong prove that there is an increase in teacher's professionalism through the development of PCK and linking it with technology (Chan \& Yung, 2015; Gray, Thomas, \& Lewis, 2010). Related to teachers' preparation, TPACK is also needed because learning the material with technology is very different from teaching material using technology (Niess, 2005). Karolčík \& Čipková (2017) found that the successful integration of digital technology into chemistry teaching not only through building technological infrastructure, but also by supporting methodological training in the form of training for teachers aimed at increasing their competency.

TPACK instruments are presented in various forms, e.g.: Worked Examples (Bajracharya, 2019) and modules (White \& Geer, 2013; Jwaid, Clark, \& Ireson, 2014). Hence, in order to satisfy the needs of this digital age, there is an urgent requirement to produce websitebased TPACK instruments. Another reform in the TPACK development is demonstrated by Harris \& Hofer (2011) who construct TPACK for teachers by using the LAT taxonomy to plan lessons, projects, and units that combine educational technology and good education ways in a focused curriculum and pedagogy. The use of integrated instruments such as this makes it possible for teachers to design curriculum-based learning via appropriate technology (Harris \& Hofer, 2006; 2009). Hence, it can be deduced that website-based TPACK by linking technology in learning preparation may be produced. Website construction is divided in terms of technical framework and implementation in learning. As a technical framework the website is able to provide meaningful experiences to users in terms of interaction, effectiveness, efficiency, completeness, construction, navigation, responsiveness, and coherence (Norman, 2013; Lee \& Kozar, 2012; Venkatesh \& Agarwal, 
2006; Shneiderman \& Plaisant, 2005). Based on the overview of its implementation, the website can be realized in e-learning by integrating bases that are in accordance with the purpose of its use, such as integrating TPACK with e-learning.

Website-based technology significantly increases learning outcomes and HOTS among students who use it compared to students who do not use website media (Akhyar, 2017; Hayati, Sutrisno \& Lukman, 2012). Online learning leads to knowledge construction, and Peters (1967) argues that online learning encourages selfautonomy in learning and lateral thinking rather than linear thinking. The W3C standard defines a Web Platform for application development that has unprecedented potential to enable developers to create a good interactive experience (W3C, 2008). E-Learning can also be used as a medium to help teachers prepare learning instruments and learn about pedagogy. This media may increase motivation of teachers to carry out teaching and learning (Kosasi, 2015). Especially in developing the website itself, as an official site in schools and agencies the website must meet the standards specified (Harper \& de Waters, 2008). Motivation can be an aspect that increases the teacher's pedagogical competence related to the standardized website content quality.

Based on the above previous studies, there is a need for technology-based learning However, this may actually become an obstacle namely the difficulty of teachers' adaptation to the modernization of learning. TPACK, which integrates technology, teaching theory, and learning theory, can be a solution. TPACK can be a strategy and guide for teachers to use technology, learn learning theories and electronic learning. Currently, the TPACK instrument is still a print module that is used by teachers in learning preparation. Therefore, in accordance with the current technological development and considering the novelty, the TPACK instruments is developed based on the website. Hence, the purposes of this study are 1) to develop a website-based TPACK instrument that is feasible for science teachers, and 2) to determine the effect of the produced website-based TPACK instruments toward the pedagogy competence of science teachers. Moreover, to focus upon the design of this study, the research questions are given as follows: how to develop a proper, practical, and effective TPACK instruments to improve pedagogical competence of junior high schools teachers?

\section{METHODS}

This is a development research applying the ADDIE model. The ADDIE model consists of 5 (five) stages, namely analyze, design, develop, implement, and evaluate (Branch, 2009). This study develops TPACK instruments in the content form. Each component in the TPACK is integrated in one learning sub-material. Each guide, tutorial, content, document file and video is placed on the menu. The menu used is adjusted to the learning material title. The TPACK framework that precisely integrates technology and pedagogy in accordance with the material is manifested in the website content in one meeting submenu. Each meeting consists of essential material (CK element), material objectives and learning scenarios (PK element), and simulations (TK element). The TK element is also included on other parts of the website, namely learning technology that contains tutorial videos for using projectors and making simple presentations.

The analysis phase is the process of determining and defining the development goals and the necessary needs. At this stage of analysis, school analysis, product resource analysis, TPACK analysis, material analysis, and science concepts are described.

The design phase aims to update the plan for making the desired product with the appropriate testing method. Planning consists of 5 stages carried out before the product and instrument are applied at a later stage. These 5 stages are 1) preparation of aspects and indicators of the TPACK instruments, 2) preparation of website aspects and indicators, 3) preparation of the concept of the website-based TPACK instruments, 4) preparation of the TPACK validation instrument, and 5) preparation of the website validation instrument.

The development stage is the actualization process from the previous design stage. The development stage consists of 4 (four) stages, namely 1) construction of the web-based TPACK instruments, 2) product validation, 3) instrument validation, and 4) product testing. The construction of the products uses the format given in Table 1. 
Table 1. Website-Based TPACK Construction Format

\begin{tabular}{lll}
\hline Meeting & $\begin{array}{l}\text { TPACK } \\
\text { Component }\end{array}$ & Website Content \\
\hline I & TK & $\begin{array}{l}\text { Energy, work, and displacement simulations; The effect of work } \\
\text { on displacement simulation } \\
\text { Learning objectives; Demonstration inquiry learning method } \\
\text { theory; Demonstration inquiry learning scenarios } \\
\text { The essential material of work and power }\end{array}$ \\
& PK & Pulley simulation I; Pulley simulation II \\
II & CK & Learning objectives; Theory of open inquiry learning method; \\
& TK & Open inquiry learning scenarios \\
& PK & Pulley essential material, mechanical advantage, and types of \\
& simple machine \\
& CK & Lever simulation; Axle wheel simulation \\
Learning objectives; Theory of problem based learning method; \\
III
\end{tabular}

This stage is an advanced stage in development research. The implementation carried out in this study is conducted upon the application and adjustment of the theory to the development of the instruments carried out.

The purpose of the Evaluation phase is to assess the quality of the product and the instructional process, both before and after implementation. The general procedures related to the Evaluation phase are the data analysis technique and product improvement if necessary. In accordance with the procedure described in ADDIE, this stage is a revision of the websitebased TPACK instruments. This revision is based on the results of expert assessments. The conclusion of the assessment is obtained from the feasibility test calculations of the TPACK instrument and website, which are given in Table 2 and Table 3 , respectively.

Table 2. TPACK Instrument Feasibility

\begin{tabular}{ll}
\hline Range of Score & Criteria \\
\hline $68.0 \leq M \leq 85.0$ & Very feasible \\
$51.0 \leq M<68.0$ & Feasible \\
$34.0 \leq M<51.0$ & Less feasible \\
$17.0 \leq M<34.0$ & Not feasible \\
\hline
\end{tabular}

Table 3. Website Feasibility

\begin{tabular}{ll}
\hline Score Range & Criteria \\
\hline $72.0 \leq M<90.0$ & Very feasible \\
$54.0 \leq M<72.0$ & Feasible \\
$36.0 \leq M<54.0$ & Less feasible \\
$18.0 \leq M<36.0$ & Not feasible \\
\hline
\end{tabular}

Moreover, the rating scale is categorized in four (4) criteria according to Mardapi (2008), which may be observed in Table 4 where $M_{i}$ is the mean ideal (half of sum of minimum and maximum scores), $S D_{i}$ is the average score, $\Sigma x$ is the sum of the values in a set of scores, and $n$ is the number of the rater.

Table 4. Rating Scale Criteria

\begin{tabular}{ll}
\hline Score Range & Criteria \\
\hline$M_{i}+1.5 S D_{i} \leq \bar{M}_{\leq M_{i}+3.0 S D_{i}}$ & Very feasible \\
$M_{i}+0 S D_{i} \leq \bar{M}_{<M_{i}+1.5 S D_{i}}$ & Feasible \\
$M_{i}-1.5 S D_{i} \leq \bar{M}_{<M_{i}+0 S D_{i}}$ & Less feasible \\
$M_{i}-3 S D_{i} \leq \bar{M}_{<M_{i}-1.5 S D_{i}}$ & Not feasible
\end{tabular}


Furthermore, the TPACK instruments that have been produced and evaluated are then tested, i.e.: limited and field tests. The limited test is conducted upon three science teachers (as respondents) from State Junior High School (SMP) 3 Luwuk and State Junior High School 4 Luwuk Central Sulawesi, to determine the effect of the TPACK instruments toward the teachers' pedagogy competence. The result of this test is compared to the initial condition based on the value of the 2015 Teachers Competence Test (Uji Kompetensi Guru - UKG) of pedagogy competence aspect. The initial average value of teachers' pedagogy competency aspect in Luwuk District is 49.93, which is a low criterion of graduation standard. Moreover, the samples in the field trials are 10 teachers from 5 junior high schools in Luwuk, Central Sulawesi.

The data gathering is conducted via observation, pre-test, and post-test. The data is obtained from four meetings according to the number of topics contained in the TPACK instruments. These topics consist of i) Work, ii) Pulleys and Axle Wheels, III) Slope and Leverage, and iv) Working Principle of Simple Machine in the Human Motion System. The data retrieval instruments in this study include pre-test sheet, post-test sheet, and product assessment sheet. The results of the data analysis from pre-test and post-test are in the form of gain score. The data analysis from the product assessment of the field trial is done using Rasch application (Maryati et al., 2019; Mokshein, Ishak, \& Ahmad, 2019). The data interpretation of the Rasch application is conducted via person criteria and reliability item, mean square value, and ZSTD value, which are given in Tables 5, 6, and 7 , respectively.

Table 5. Person Criteria and Item Reliabilities

\begin{aligned} & \hline Score Criteria \\ & \hline$<.67$ Weak \\ & $.67-.80$ Intermediate \\ & $.80-.90$ Good \\ & $.91-.94$ Very good \\ &$>.94$ Exceptional \\ & \hline\end{aligned}

Table 6. Mean-Square Value Interpretation

\begin{aligned} & \hline Score Implication on Measurement \\ & \hline$>2.0 \begin{array}{l}\text { Decreasing the quality of } \\ \text { measurement system }\end{array} \\ & 1.5-2.0 \begin{array}{l}\text { Less good for producing } \\ \text { instrument but does not } \\ \text { decrease the quality }\end{array} \\ & .5-1.5 \begin{array}{l}\text { A good condition for } \\ \text { measurement }\end{array} \\ & \begin{array}{l}\text { Less productive } \\ \text { measurement, but does not } \\ \text { decrease the quality; possibly } \\ \text { can produce error with high } \\ \text { reliability }\end{array} \\ &$\hline\end{aligned}

Table 7. ZSTD Value Interpretation

\begin{tabular}{cl}
\hline Score & Implication on Measurement \\
\hline$\geq 3.0$ & $\begin{array}{l}\text { The data is not expected if it fits } \\
\text { the model (perfectly), however } \\
\text { with a large data sample the } \\
\text { discrepancy may be smaller }\end{array}$ \\
$2.0-2.9$ & $\begin{array}{l}\text { The data seems to be } \\
\text { unpredictable }\end{array}$ \\
$-1.9-1.9$ & $\begin{array}{l}\text { The data has a logical estimation } \\
\leq-2\end{array}$ \\
\hline
\end{tabular}

Rasch analysis is also equipped with the separation of Strata $(H)$ that can be expressed in the following equation:

$H=\frac{[(4 \times S E P A R A T I O N)+1]}{3}$

where SEPARATION is the value of the separation of the ministep outcomes.

\section{FINDINGS AND DISCUSSION Findings}

The analysis phase, which is divided into several sections, shows information in the field, especially in the school environment. The analysis of the school provides information about the lack of complex examples of Work and Simple Machine physics materials to be taught in school. Hence, students can use simulations to visually observe the number of forces in the system involving the concept of Work and Simple Machine. To help realize the ease of media use, 
the resource analysis shows the compatibility of implementing WordPress Content Management System (CMS). In addition to ease of use, this application framework is more flexible to be adapted with the resources of the class. As media used by the teacher, making a website based on the TPACK stage, TPACK analysis shows the need for reinforcement in certain sections. The TK that needs to be reinforced is the simulations, guidelines for using the simulations, guidelines for using technology in class, and guidelines for using the website. The PK that needs to be reinforced is the syllabus, learning objectives, learning methods, learning scenarios, student project activities, and assessment guides. The final analysis is the analysis of teaching materials, which shows the topics of Work and Simple Machines as the most suitable topics because they have all the elements of TPACK development.

The implementation stage is carried out by testing the TPACK instruments on teachers and media experts. The teachers and media experts consist of five (5) people, who are all raters and given the TPACK evaluation instrument. The design stage that is carried out produces indicators for each aspect as given in Table 8 . Actualization of design in the develop stage of ADDIE generates a website-based TPACK instruments in accordance with the theory used. The website construction format may be observed in Table 9.

Table 8. Guidelines for Developing a Website-Based TPACK Instrument

\begin{tabular}{ll}
\hline Aspect & Indicator \\
\hline TK & $\begin{array}{l}\text { Provide the ability and knowledge of teachers in using technology to help } \\
\text { the learning process. This technology can be in the form of software and } \\
\text { hardware. }\end{array}$ \\
& $\begin{array}{l}\text { Provide the ability and knowledge of teachers to choose and determine } \\
\text { the learning methods and approaches that are appropriate to the } \\
\text { conditions of students and the learning material. }\end{array}$ \\
& $\begin{array}{l}\text { Provide the ability and knowledge of teachers in mastering the material } \\
\text { and learning concept given to students. These materials and concepts } \\
\text { relate to the completeness and suitability of the teacher's knowledge with } \\
\text { the understanding of students so that learning can be more meaningful. }\end{array}$ \\
\hline
\end{tabular}

Table 9. Website Construction Format Based on the Synthesis Results

\begin{tabular}{|c|c|}
\hline Aspect & Indicator \\
\hline Web design and application & $\begin{array}{l}\text { 1. Web design and application that is easy to understand with a } \\
\text { brief navigation. }\end{array}$ \\
\hline Web device & $\begin{array}{l}\text { 2. Good website accessibility with smooth access to certain } \\
\text { devices. }\end{array}$ \\
\hline \multirow[t]{2}{*}{ The semantic web } & $\begin{array}{l}\text { 3. Audio and video used contain important information with } \\
\text { good quality. }\end{array}$ \\
\hline & $\begin{array}{l}\text { 4. The use of small storage so that the website can be accessed } \\
\text { quickly even though the Internet network speed is low. }\end{array}$ \\
\hline XML technology & $\begin{array}{l}\text { 5. Content such as physics, chemistry, biology or other } \\
\text { mathematical equations are not displayed in image forms. }\end{array}$ \\
\hline
\end{tabular}

The main product can be seen at the URL address https://guruku.website with the display illustrated in Figure 1. The display in Figure 1 consists of three parts of the website, i.e.: the front-page, the content (learning instruments and technology), and the last page. The frontpage contains 'Selamat Datang Guruku' (in Indonesia) or 'Welcome My Teacher' (English translation). 


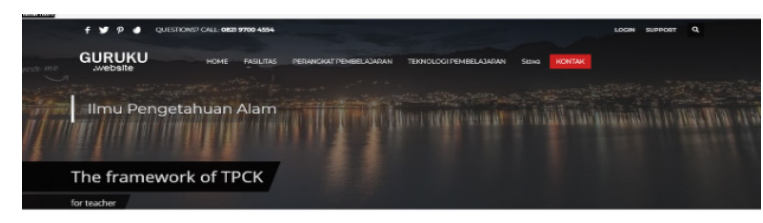

SELAMAT DATANG GURUKU $\bullet$
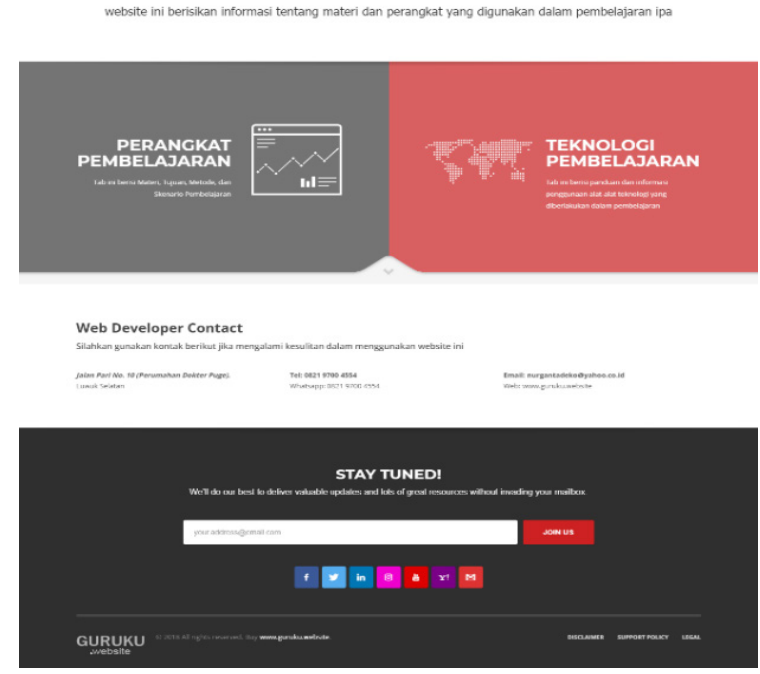

Figure 1. Homepage of the TPACK Website

The results of product validation carried out through assessments of the website media and material experts for the TPACK instruments are shown in the Tables 10 and 11, respectively. The TPACK instrument validation results show that the aspects of TK, PK, and CK of the instruments are very feasible to be used. Moreover, the website validation results show that the TPACK website is also feasible.

Table 10. Results of TPACK Instrument Validation

\begin{tabular}{lcl}
\hline Aspect & Value/Max & Conclusion \\
\hline TK & $30 / 36$ & \\
PK & $32 / 32$ & Very feasible \\
CK & $8 / 8$ & \\
Total & $70 / 76$ & \\
\hline
\end{tabular}

Table 11. Website Validation Results

\begin{tabular}{lcl}
\hline Aspect & $\begin{array}{c}\text { Value/ } \\
\text { Max }\end{array}$ & Conclusion \\
\hline Web design and & $32 / 45$ & \\
application & & \\
Web-device & $12 / 20$ & Feasible \\
Semantic web & $12 / 20$ & \\
XML technology & $5 / 5$ & \\
Total & $60 / 90$ & \\
\hline
\end{tabular}

The results of limited trials in Table 12 shows that the product evaluation by users (science teachers) gives a Very Good category. Moreover, Table 13 shows that the product developed can positively influence teacher pedagogical competence with an average of Good category. This means that TPACK instruments can be used to prepare science teachers before learning. Furthermore, the gain value is also obtained based on observations and teacher questionnaires. Before using TPACK instruments, science teachers' pedagogical competencies are 8.3 and 66.9, respectively. However, after using the TPACK instruments the pedagogical competencies increase to 13.25 and 80.3 with a gain value of .44 and .38 (see Table 14), respectively. These results also show that product can be field tested.

Table 12. The Categories of Product Evaluation by Users

\begin{tabular}{|c|c|c|}
\hline Respondent & $\begin{array}{c}\text { Product } \\
\text { Evaluation }\end{array}$ & Category \\
\hline K402A & 146 & Very good \\
\hline M402A & 148 & Very good \\
\hline B301A & 163 & Very good \\
\hline \multicolumn{2}{|c|}{ Summary } & Very good \\
\hline
\end{tabular}

Notes: $140 \leq M \leq 175=$ Very good; $105 \leq M<140=$

Good; $70 \leq M<105=$ Less good; $35 \leq M<70=$ Not good

Table 13. The Criteria of Teachers' Pedagogy Competence in the Limited Test

\begin{tabular}{lcl}
\hline Respondent & $\begin{array}{c}\text { Pedagogy } \\
\text { Competence Score }\end{array}$ & Category \\
\hline B301A & 80.0 & Very good \\
M402A & 65.0 & Good \\
K402A & 75.0 & Very good \\
\hline & $\mathbf{7 3 . 3}$ & Good \\
\hline
\end{tabular}

Notes: $75.0 \leq M \leq 100.0=$ Very good; $50.0 \leq M<75.0$

= Good; $25.0 \leq M<50.0$ = Less good; $.0 \leq M<25.0$

$=$ Not good

Table 14. Gain Score of Teachers' Pedagogy Competence

\begin{tabular}{|c|c|c|c|}
\hline \multirow{2}{*}{ Data Source } & \multicolumn{2}{|c|}{ Use of TPACK Website } & \multirow{2}{*}{ Gain } \\
\hline & Before & After & \\
\hline Observation & 8.3 & 13.25 & .44 \\
\hline Questionnaire & 66.9 & 80.30 & .38 \\
\hline
\end{tabular}


The result obtained from the field test is presented in Appendix 1. The results of the analysis of the Appendix 1 can be realized in Figure 2.

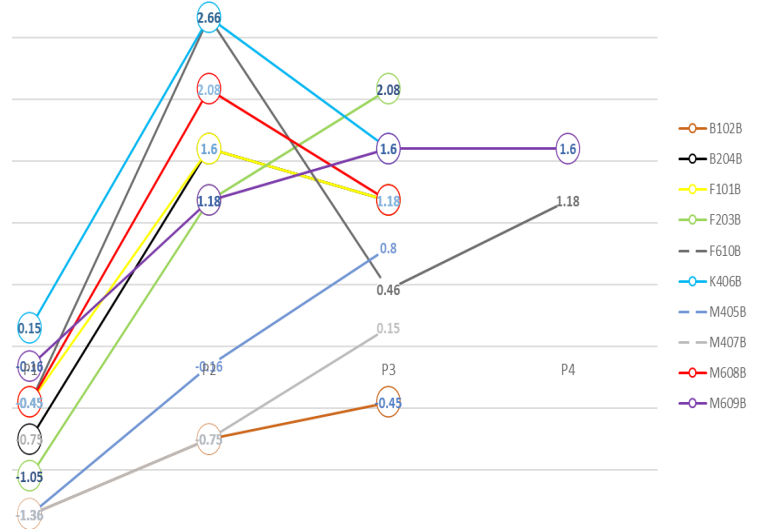

\section{Figure 2. The Dynamics of Science Teachers' Pedagogy Competence for each Topic or Meeting (P1, P2, P3, and P4)}

It can be observed in Figure 2 that there is an increase in the science teachers' pedagogical competence from the first topic (P1) to the second topic (P2) for all respondents. However, there are decreasing (K406B, M608B, F101B; $\mathrm{B} 204 \mathrm{~B}$ ) and increasing (F203B; M609B; K406B; M407B; B102B) pedagogical competence when heading to the third topic (P3). For the fourth topic (P4) most of the respondents have not completed use of the product so there are only two complete samples namely B204B and $\mathrm{M} 609 \mathrm{~B}$, each showing an increase and no change in pedagogical competency, respectively. Furthermore, the mean square obtained from the field trial is .52 , which means it is in the criteria of 'a good condition for measurement' in accordance with Table 6.

\section{Discussion}

The development process carried out produces a TPACK website that is used by teachers before learning. This website is used by science teachers in order to prepare learning materials in the form of media to teach science concepts in the classroom with the most appropriate learning method. In the first meeting, the teacher had studied the TPACK website contents including the learning scenarios, learning theories, essential science materials, and the technology that were directly related to the subject material in the meetings. After studying the website contents of each meeting, the teacher is directly guided to carry out the learning stages. During the teaching and learning activities, the teacher can show the science material in a form of PowerPoint (PPT) presentation for the simulation directly from the TPACK website. This is because the TPACK website is made primarily for the science teacher. Not only simulation from the website, the teacher was also seen showing examples of the science concept applications using simple teaching aids that were still related to the simulations in the website. In the second meeting to the fourth meeting, the teaching and learning activities were also conducted with the same stages by the teacher. However, the teacher also practiced different learning method at each meeting in accordance with learning scenarios in the website. Moreover, all instruments used in the website are in accordance with the 2013 Curriculum of Indonesia. This adjustment is made so that there is no overlap between the Curriculum and the newly developed instruments.

The results of the analysis show three important findings. First, the school analysis provides an overview of schools taken from the province of Central Sulawesi Indonesia. Schools in these areas have Internet facilities and other supporting instruments. The product construction is very possible to be used in the classroom and in every teacher's cell phone before learning begins or at home. Second, product resource analysis shows that there is no analogy algorithm in a very complicated programming language. These results lead to the use of WordPress CMS, which is sufficient for the needs of teachers. The use of WordPress also makes it easier to develop other learning facilities. Third, TPACK analysis shows the similarity of perceptions from various reference sources. These similarities are summarized into three aspects, namely TK, PK, and CK. These three aspects are considered to be the basis that teachers must have in learning through the website. Finally, the material analysis and the science concept show the existence of synergy between learning in the classroom that can be conducted by the teacher with learning theory.

This study uses the materials of Work and Simple Machine in grade VII of junior high school. In accordance with the 2013 Indonesian Curriculum, the materials are divided into 
4 meetings with their respective learning objectives. Each meeting contained learning theories in the form of learning scenarios, namely demonstration inquiry, open inquiry, and problem based learning. For the continuation of this scenario, the website provides physics simulations from http://phet.colorado.edu and https://www.thephysicsaviary.com.

The instrument validation is conducted by the media and material experts. The results of the validation through the feasibility test show that the TPACK instruments and the website developed are feasible for use by teachers in preparation before learning in class. The validation results indicate the feasibility of the product used by the teacher. This is observed from the results of the feasibility test which reaches 60 from the maximum value of 90 for the feasibility of the website. The feasibility of the TPACK instruments that is manifested in the website contents obtains a value of 70 out of a maximum value of 76 . Website development assessed from aspects as in Table 5 and Table 6 are the aspects assessed from the TPACK instruments. The preparation of the TPACK instruments has an almost perfect value from the experts. This may be observed from the aspect of TK that has a difference of fewer than 10 in the guidelines for the technology use and theory proving simulations. Other aspects, viz.: PK and CK have perfect assessments.

The use of the website as a TPACK instrument media also resulted in a good category. The highest score is obtained from the aspects of Web Design and Application. Overall experts provide an objective assessment. This relates to the use of simulations obtained from several popular websites. The purpose of using simulations and instructions from popular websites is to utilize good media from professional people.

The website-based TPACK instruments that have been developed provide new knowledge. The development carried out has resulted in an integrated instrument for teachers. As a preparation before learning, the teacher can deepen his or her knowledge of the theory in the material presented. Not only theory in the material, this media is used to deepen the knowledge of learning theory used by teachers in the classroom. As expressed in the theory of PK, teachers must be able to use variations of learning theory in accordance with the material being taught.

The TPACK instrument that was compiled based on the applicable curriculum (2013 Indonesia curriculum) becomes an effort made to strengthen teacher's professionalism. This is in accordance with a study conducted by Koh, Chai, \& Lim (2016) that integrated TPACK instrument of curriculum; learning scenarios; and technology selection can provide improved pedagogical competence for science teachers compared to TPACK partially. The basis of online learning on the TPACK instrument is the most important part of development, which can invade the realm of technology in the $21^{\text {st }}$ century literacy. This instrument contains concise and contextual use of technology guidelines through video tutorials as recommended in a study conducted by Alrwaished, Alkandari, \& Alhashem (2017). The TPACK framework can help teachers in online learning by providing guidelines for the effective use of technology (Ouyang \& Scharber, 2018; Papanikolaou, Makri, \& Roussos, 2017; Martin, 2015). These technology guidelines can also increase technological literacy knowledge for teachers and also for students who use it directly in learning (Tan \& Ali, 2019; Voogt \& McKenney, 2016). In addition, this TPACK instrument was developed to provide a more comprehensive learning experience with important elements in it. In accordance with a study conducted by Drajati, Tan, Haryati, Rochsantiningsih, \& Zainnuri (2018) TPACK can help develop learning comprehensively and not only functioned as media development, but also may be used effectively in learning. Direct use of the instrument may also help teachers in their preparation related to technological knowledge (Graham, Burgoyne, Cantrell, Smith, Clair, \& Haris, 2009).

The results of the limited and field tests show that the website-based TPACK instruments positively affect the pedagogical competence of science teachers. This is also supported by the results of observation and questionnaire of teachers before and after the use of TPACK instruments viewed from the gain value. However, science teachers' pedagogical competence depends also on the topic in the website-based TPACK instruments. Teachers' pedagogical competence increases from the first topic to the second topic, but some drop and some 
increase for the third topic. The increase from the first topic to the second topic can be caused by the dominant mastery of the second topic, i.e.: Pulleys and the Axle Wheels, by all respondents compared to that of the third topic (Slope and Leverage). This means that the science teachers' pedagogical competence is influenced by the use of TPACK instruments that are manifested in the science teachers' professionalism (Syamsuriyanti \& Sukirno, 2018). However, the use of TPACK instruments still needs to be improved in order to further increase the science teachers' pedagogical competence (Maryati et al., 2019).
The website-based TPACK instruments are said to be effective in improving science teachers' pedagogical competence is supported by the pedagogical competency indicators, which include: i) formulation of the learning objectives, ii) formulation of the learning method, and iii) learning scenario. These indicators are evaluated from the lesson plan instruments before and after the use of the TPACK website. All three indicators have experienced significant changes before and after the use of the TPACK website. An example of the changes in the learning objective may be observed in Table 15 .

Table 15. The Learning Objective before and after the Use of the Tpack Website

\begin{tabular}{|c|c|}
\hline $\begin{array}{l}\text { Use of TPACK } \\
\text { Website }\end{array}$ & Learning Objective \\
\hline \multirow[t]{3}{*}{ Before } & $\begin{array}{l}\text { After following the learning process, students are expected to: } \\
\text { 1. Classify various kinds of materials; }\end{array}$ \\
\hline & 2. Identify differences between elements, compounds, and mixtures; \\
\hline & $\begin{array}{l}\text { 3. Make observations of objects around them and classify the objects based on } \\
\text { their constituent materials. }\end{array}$ \\
\hline \multirow[t]{2}{*}{ After } & $\begin{array}{l}\text { 1. Through observation and discussion activities, students are able to identify } \\
\text { the characteristics of solid, liquid, and gas materials correctly in accordance } \\
\text { to the learning sources. }\end{array}$ \\
\hline & $\begin{array}{l}\text { 2. Through observation, students are able to classify physical and chemical } \\
\text { properties, and also physical and chemical changes correctly in accordance to } \\
\text { the learning sources. }\end{array}$ \\
\hline
\end{tabular}

It may be observed in Table 15 that the learning objective before the use of TPACK website does not show the condition and degree aspects. However, after the use of the TPACK website, the condition and degree aspects appear in 'observation and discussion' and 'in accordance to the learning sources', respectively. Moreover, an example of the changes before and after the use of the TPACK website concerning the learning method can be seen in Table 16.

Table 16. The Learning Methods before and after the Use of the TPACK Website

\begin{tabular}{ll}
\hline $\begin{array}{l}\text { Use of TPACK } \\
\text { Website }\end{array}$ & Learning Methods \\
\hline Before & $\begin{array}{l}\text { Classical, discussion, and } \\
\text { experiment } \\
\text { Observation and } \\
\text { discussion }\end{array}$ \\
\hline
\end{tabular}

It can be observed in the Table 16 that the learning methods before the use of the TPACK website consist of classical, discussion, and experiment methods. However, these methods do not appear in the learning objective as a process in Table 15. This means that the method stated is not relevant to the learning activities. On the other hand, after the use of the TPACK website, the learning method becomes relevant to the learning activities and stated in the learning objective as a process or condition.

The TPACK instrument contains learning scenarios that are part of the teacher's preparation. The use of learning scenarios prepared in the TPACK as learning media for teachers can help the success of learning and the development of teacher's professionalism (Sickel, 2019). An example of the learning scenario before and after using the TPACK website is given in Table 16. Before using the TPACK website, teachers prepare the learning scenario that is out of sync 
with the learning method and process that are formulated in the learning objectives. However, after the use of the TPACK website the scenario is in accordance with the learning method (i.e.: observation and discussion - see Table 17) and also learning process in the learning objectives.

Table 17. The Learning Scenarios before and after the Use of the TPACK Website

\begin{tabular}{lll}
\hline $\begin{array}{l}\text { Use of TPACK } \\
\text { Website }\end{array}$ & Learning Scenario & \\
\hline Before & Information gathering & $\begin{array}{l}\text { Students take note of observation results in the } \\
\text { worksheet. } \\
\text { Students conduct literature study (via student book } \\
\text { or internet) about element, compound, and mixture. } \\
\text { Students take note of the observation results in the } \\
\text { worksheet. }\end{array}$ \\
After & Information gathering & $\begin{array}{l}\text { Students conduct discussion and make summary } \\
\text { from the observation results. }\end{array}$ \\
\hline
\end{tabular}

\section{CONCLUSIONS}

The products obtained in this study constructed based on theories about TPACK and websites can be used for preparation of teacher before learning in class. The results of the feasibility test analysis show that the TPACK instruments and the website are theoretically feasible. Moreover, the limited and field-tests show that the use of the website-based TPACK instruments positively affects the pedagogy competence of science teachers. The websitebased TPACK instruments usage by users are viewed with an overall Very Good category. Based on the observation and questionnaire the pedagogy competence of science teachers increases after the use of the TPACK instruments. This study also recommends using a shorter application framework so that it can be used simultaneously as media for teachers and students for a more contextual use. Furthermore, the aforementioned recommendation can provide a more complex flow from the preparation to evaluation of learning. The learning topics that only apply to three meetings (according to the curriculum), resulted in the use and assessment of media being very short, which becomes a limitation in this study.

\section{AKNOWLEDGMENTS}

The authors would like to thank the Graduate Program of Universitas Negeri Yogyakarta as well as other related institutions for supporting this study.

\section{REFERENCES}

Akhyar, M. (2017). Pengembangan media pembelajaran IPA scientific approach on website (science-on-web) untuk meningkatkan kemandirian dan hasil belajar siswa SMP. [Developing learning media of scientific approach on website (science-on-web) to improve selfregulated learning and students learning outcomes at junior high school]. (Master Thesis, Universitas Negeri Yogyakarta). http://eprints.uny.ac.id/51467.

Allen, I. E. \& Seaman, J. (2003). Sizing the opportunity: The quality and extent of online education in the United States, 2002 and 2003. USA: Sloan Consortium (NJ1).

Alrwaished, N., Alkandari, A., \& Alhashem, F. (2017). Exploring in- and pre-service science and mathematics teachers' technology, pedagogy, and content knowledge (TPACK): What next. Eurasia Journal of Mathematics, Science and Technology Education, 13(9), 6113-6131. https://doi.org/10.12973/ eurasia.2017.01053a.

Bajracharya, J. R. (2019). TPACK-integrated worked examples for technology integration. Journal of Training and Development, 4(2019), 46-63. https://doi. org/10.3126/jtd.v4i0.26837. 
Balçın, M. D., \& Ergün, A. (2017). Science teacher candidates' views about technological pedagogical content knowledge (TPACK). Journal of Theory and Practice in Education, 13(4), 570600. http://dergipark.gov.tr/http-ekucomu-edu-tr/issue/31729/347789.

Branch, R. M. (2009). Instructional design: The ADDIE approach. New York: Springer. https://doi.org/10.1007/978-0-38709506-6.

Chan, K. K. H., \& Yung, B. H. W. (2015). Onsite pedagogical content knowledge development. International Journal of Science Education, 37(8), 1246-1278. https://doi.org/10.1080/09500693.2015.1 033777 .

Doering, A., Veletsianos, G., Scharber, C., \& Miller, C. (2009). Using the technological, pedagogical, and content knowledge framework to design online learning environments and professional development. Journal of Educational Computing Research, 41(3), 319-346. https://doi.org/10.2190/EC.41.3.d.

Drajati, N. A., Tan, L., Haryati, S., Rochsantiningsih, D., \& Zainnuri, H. (2018). Investigating English language teachers in developing TPACK and multimodal literacy. Indonesian Journal of Applied Linguistics, 7(3), 575-582. https://doi.org/10.17509/ijal.v7i3.9806.

Graham, C. R., Burgoyne, N., Cantrell, P., Smith, L., Clair, L. St., \& Haris, R. (2009). TPACK development in science teaching: measuring the TPACK confidence of inservice science teachers. Tech Trends, 53(5), 70-79. https://doi.org/10.1007/ s11528-009-0328-0.

Gray, L., Thomas, N., \& Lewis, L. (2010). Teachers' use of educational technology in U.S. Public Schools: 2009. Alexandria, VA: National Center for Education Statistics.

Harper, K. A., \& de Waters, J. (2008). A quest for website accessibility in higher education institutions. The Internet and Higher
Education, 11(3-4), 160-164. https://doi. org/10.1016/J.IHEDUC.2008.06.007.

Harris, J. B., \& Hofer, M. J. (2011). Technological pedagogical content knowledge (TPACK) in action: A descriptive study of secondary teachers' curriculum-based, technologyrelated instructional planning. Journal of Research on Technology in Education, 43(3), 211-229. https://doi.org/1080/153 91523.2011.10782570.

Harris, J., \& Hofer, M. (2006, July). Planned improvisations: Technology-supported learning activity design in social studies. Paper presented at the National Educational Computing Conference, San Diego, CA. http://center.uoregon. edu/ISTE/NECC2006/program/search results details.php?sessionid $=13514149$.

Harris, J., \& Hofer, M. (2009, 2 March). Instructional planning activity types as vehicles for curriculum-based TPACK. Paper presented at the Society for Information Technology \& Teacher Education International Conference, Charleston, SC. https://www.learntechlib. org $/ \mathrm{p} / 31298$.

Hunter, J. (2015). Technology integration and high possibility classrooms building from TPACK. New York, NY: Routledge.

Indonesian Science Educators Association. (2015). Learning outcome. Semarang: Perkumpulan Pendidik IPA Indonesia.

Jwaid, A. E., Clark, S., \& Ireson, G. (2014). Understanding best practices in control engineering education using the concept of TPACK. In Proceeding of 2014 IEEE Integrated STEM Education Conference. Princeton, NJ; IEEE, pp. 1-6. https://doi. org/10.1109/ISECon.2014.6891027.

Karolčík, Š., \& Čipková, E. (2017). Attitudes among chemistry teachers towards increasing personal competencies in applying ICT. Chemistry Didactics Ecology Metrology, 22(1-2), 99-121. https://doi.org/10.1515/cdem-2017-0006.

Koehler, M. J., Mishra, P., \& Cain, W. (2013). 
What is technological pedagogical content knowledge (TPACK)? Journal of Education, 193(3), 13-19. https://doi. org/10.1177/002205741319300303.

Koh, J. H. L., Chai, C. S., \& Lim, W. Y. (2016). Teacher professional development for TPACK-21CL. Journal of Educational Computing Research, 55(2), 172-196. https://doi. org/10.1177/0735633116656848.

Kosasi, S. (2015). Perancangan e-learning untuk meningkatkan motivasi belajar guru dan siswa. [The design of e-learning to increase the motivation of learning of teachers and students]. In Proceeding of the Seminar Nasional Pendidikan Teknik Informatika (SENAPATI). Bali: Undiksa, pp. 82-88. http://www.jurnal.stmikpontianak.ac.id.

Lee, Y., \& Kozar, K. A. (2012). Understanding of website usability: Specifying and measuring constructs and their relationships. Decision Support Systems, 52(2), 450-463. https://doi.org/10.1016/j. dss.2011.10.004.

Mardapi, D. (2008). Teknik penyusunan instrumen tes dan nontes. [Techniques of preparing test and non-test instrument]. Yogyakarta: Mitra Cendikia Press.

Martin, B. (2015). Successful implementation of TPACK in teacher preparation programs. International Journal on Integrating Technology in Education, 4(1), 17-26. https://doi.org/10.5121/ijite.2015.4102.

Maryati, Prasetyo, Z. K., Wilujeng, I., \& Sumintono, S. (2019). Measuring teachers' pedagogical content knowledge using many-facet Rasch model. Cakrawala Pendidikan, 38(3), 452-462. https://doi. org/10.21831/cp.v38i3.26598.

Mokshein, S. E., Ishak H., \& Ahmad, H. (2019). The use of Rasch measurement model in English testing. Cakrawala Pendidikan, 38(1), 16-32. https://doi.org/10.21831/ cp.v38il.22750.

National Science Teachers Association. (2012). Pre-service science standards. https://
www.nsta.org/preservice/docs/2012NST APreserviceScienceStandards.pdf.

Niess, M. L. (2005). Preparing teachers to teach science and mathematics with technology: Developing a technology pedagogical content knowledge. Teaching and Teacher Education, 21(5), 509-523. https://doi. org/10.1016/J.TATE.2005.03.006.

Norman, D. (2013). The design of everyday things. New York, NY: Basic Books.

Novkovic-Cvetkovic, B., \& Stanojevic, D. (2017). Educational needs of teacher for introduction and application of innovative models in educational work to improve teaching. International Journal of Cognitive Research in Science, Engineering and Education, 5(1), 49-56. https://doi.org/10.5937/ IJCRSEE1701049N.

Ouyang, F., \& Scharber, C. (2018). Adapting the TPACK framework for online teaching within higher education. International Journal of Online Pedagogy and Course Design, 8(1), 42-59. https://doi. org/10.4018/IJOPCD.2018010104.

Papanikolaou, K., Makri, K., \& Roussos, P. (2017). Learning design as a vehicle for developing TPACK in blended teacher training on technology enhanced learning. International Journal of Educational Technology in Higher Education 14(34), 1-14. https://doi. org/10.1186/s41239-017-0072-z.

Peters, O. (1967). Distance education and industrial production: a comparative interpretation in outline. http://www.c31. uni-oldenburg.de/cde/found/peters67. htm.

Purwaningsih, W. P. (2016). Analisis kemampuan guru dalam menerapkan pemanfaatan teknologi informasi dan komunikasi dalam pembelajaran menggunakan kerangka TPACK: Study kasus SMA Negeri 1 Tengaran. [Analysis of the ability of teachers to apply the use of information and communication technology in learning using the TPACK framework: 
Case study at SMA Negeri 1 Tengaran]. Artikel Ilmiah Universitas Kristen Satya Wacana, 1-18. http://repository.uksw.edu/ handle/123456789/10769.

Sheffield, R., Dobozy, E., Gibson, D., Mullaney, J., \& Campbell, C. (2015). Teacher education students using TPACK in science: A Case Study. Educational Media International, 52(3), 227-238. https://doi. org/10.1080/09523987.2015.1075104.

Shneiderman, B., \& Plaisant, C. (2005). Designing the user interface: Strategies for effective human-computer interaction. Boston, MA: Addison-Wesley Longman Publishing.

Sickel, J. L. (2019). The great media debate and TPACK: A multidisciplinary examination of the role of technology in teaching and learning. Journal of Research on Technology in Education, 51(2), 152-165. https://doi.org/10.1080/15391523.2018.1 564895.

Syamsuriyanti, S., \& Sukirno, S. (2018). Determinant factors of teachers' professionalism. Jurnal Kependidikan, 2(1), 56-67. https://doi.org/10.21831/ jk.v2i1.10588.

Tan, L., \& Ali, J. (2019). Investigating TPACK as professional knowledge for Australian literacy teachers. The International Encyclopedia of Media Literacy, 1-12. https://doi.org/10.1002/9781118978238. iem10235.

Undang-Undang RI 2005 No. 14. Guru dan dosen. [Teacher and lecturer].

Van Driel, J. H., de Jong, O., \& Verloop, N. (2002). The development of preservice chemistry teachers' pedagogical content knowledge. Science Education, 86(4), 572-590. https://doi.org/10.1002/ sce. 10010 .

Venkatesh, V., \& Agarwal, R. (2006). Turning visitors into customers: A usabilitycentric perspective on purchase behavior in electronic channels. Management Science, 52(3), 367-382. https://doi. org/10.1287/mnsc.1050.0442.

Voogt, J., \& McKenney, S. (2016). TPACK in teacher education: Are we preparing teachers to use technology for early literacy? Technology, Pedagogy and Education, 26(1), 69-83. https://doi.org/1 0.1080/1475939x.2016.1174730.

White, B., \& Geer, R. (2013). Preservice teachers experience with online modules about TPACK. Australian Educational Computing, 27(3), 124-132.

Widyastono, H.(2016). Pedagogical competence. Surabaya: Genta Group Production.

W3C. (2008). Standards-W3C. https://www. w3.org/standards. 
Appendix 1. Pedagogy Competence Increase based on Rasch Application Data Analysis

\begin{tabular}{|c|c|c|c|c|c|c|c|c|}
\hline \multirow{2}{*}{$\begin{array}{c}\text { Entry } \\
\text { Number }\end{array}$} & \multirow{2}{*}{$\begin{array}{r}\text { Total } \\
\text { Score }\end{array}$} & \multirow{2}{*}{$\begin{array}{c}\text { Total } \\
\text { Count }\end{array}$} & \multirow{2}{*}{ Measure } & \multicolumn{2}{|c|}{ Infit } & \multicolumn{2}{|c|}{ Outfit } & \multirow{2}{*}{ Person } \\
\hline & & & & MNSQ & ZSTQ & MNSQ & ZSTD & \\
\hline 17 & 17 & 20 & 2.66 & .73 & -.45 & .27 & -.36 & K406BP2 \\
\hline 30 & 17 & 20 & 2.66 & 1.15 & .45 & .66 & .15 & F610BP2 \\
\hline 23 & 16 & 20 & 2.08 & .94 & .02 & 1.77 & .93 & M608BP2 \\
\hline 9 & 16 & 20 & 2.08 & 1.38 & .9 & 2.62 & 1.36 & F203BP3 \\
\hline 28 & 15 & 20 & 1.6 & .67 & -.76 & .69 & -.08 & M609BP4 \\
\hline 27 & 15 & 20 & 1.6 & 1.23 & .66 & .77 & .03 & M609BP3 \\
\hline 18 & 15 & 20 & 1.6 & 1.03 & .21 & .75 & 0 & K406BP3 \\
\hline 2 & 15 & 20 & 1.6 & .39 & -1.8 & .23 & -.95 & F101BP2 \\
\hline 11 & 15 & 20 & 1.6 & 2.56 & 2.8 & 4.92 & 2.6 & B204BP2 \\
\hline 26 & 14 & 20 & 1.18 & 1.13 & .45 & 1.23 & .54 & M609BP2 \\
\hline 24 & 14 & 20 & 1.18 & .95 & -.01 & 1.12 & .41 & M608BP3 \\
\hline 32 & 14 & 20 & 1.18 & 1.03 & .2 & 1.66 & .98 & F610BP4 \\
\hline 8 & 14 & 20 & 1.18 & 1.05 & .26 & 2.13 & 1.38 & F203BP2 \\
\hline 3 & 14 & 20 & 1.18 & .61 & -1.1 & .5 & -.57 & F101BP3 \\
\hline 12 & 14 & 20 & 1.18 & .85 & -.31 & .67 & -.24 & B204BP3 \\
\hline 15 & 13 & 20 & .8 & .97 & .01 & 1.03 & .27 & M405BP3 \\
\hline 31 & 12 & 20 & .46 & .87 & -.38 & .86 & -.02 & F610BP3 \\
\hline 21 & 11 & 20 & .15 & 1.27 & 1.07 & 1.19 & .49 & M407BP3 \\
\hline 16 & 11 & 20 & .15 & .61 & -1.72 & .45 & -.87 & K406BP1 \\
\hline 25 & 10 & 20 & -.16 & 1.13 & .61 & 1.74 & 1.11 & M609BP1 \\
\hline 14 & 10 & 20 & -.16 & 1.09 & .45 & 1.37 & .71 & M405BP2 \\
\hline 22 & 9 & 20 & -.45 & .95 & -.15 & .73 & -.14 & M608BP1 \\
\hline 29 & 9 & 20 & -.45 & 1.07 & .4 & 1.29 & .61 & F610BP1 \\
\hline 1 & 9 & 20 & -.45 & .7 & -1.49 & .52 & -.52 & F101BP1 \\
\hline 7 & 9 & 20 & -.45 & 1.05 & .28 & .84 & .02 & B102BP3 \\
\hline 20 & 8 & 20 & -.75 & .9 & -.43 & 1.38 & .68 & M407BP2 \\
\hline 10 & 8 & 20 & -.75 & .96 & -.13 & .79 & .02 & B204BP1 \\
\hline 5 & 8 & 20 & -.75 & .59 & -2.19 & .44 & -.54 & B102BP2 \\
\hline 6 & 7 & 20 & -1.05 & .68 & -1.51 & .5 & -.29 & F203BP1 \\
\hline 19 & 6 & 20 & -1.36 & .53 & -2.2 & .38 & -.44 & M407BP1 \\
\hline 13 & 6 & 20 & -1.36 & 1.3 & 1.18 & 1.16 & .5 & M405BP1 \\
\hline \multirow[t]{3}{*}{4} & 6 & 20 & -1.36 & .8 & -.77 & .56 & -.14 & B102BP1 \\
\hline & Mean & & .52 & & & & & \\
\hline & P.SD & & 1.19 & & & & & \\
\hline
\end{tabular}

